\title{
DETERMINATION OF QUALITY OF MILK FROM DIFFERENT GENOTYPE OF DAIRY COWS
}

\author{
M. R. Islam ${ }^{1}$, M. N. Hassan ${ }^{2}$, M. S. R. Siddiki ${ }^{2}$, M. A. S. Khan ${ }^{2}$ and M. A. Islam ${ }^{2}$
}

\begin{abstract}
The present study was conducted to investigate the milk quality from different genotype. A total 48 dairy cows belong to different genotypes such as Holstein cross, Jersey cross, Sahiwal cross and Red Chittagong were selected. Milk compositional viz. specific gravity, Acidity test, Fat test, Protein test, Solids-not-fat (SNF) test and total solids (TS) test were carried out. It was observed that the higher specific gravity of milk was obtained from Jersey cross and Red Chittagong genotype, which was significantly higher $(\mathrm{P}<0.01)$ than the other genotype of dairy cows. The highest acidity (\%) was observed $(0.165 \pm 0.014)$ in Red Chittagong and the lowest acidity $(0.118 \pm 0.025)$ in Sahiwal cross. The highest fat $(\%)$ was observed from Red Chittagong cows milk which was statistically higher from Jersey cross and Sahiwal cross and the lowest fat (\%) was found in the milk of Holstein cross cows. The highest SNF value was obtained from Jersey cross and the lowest from Sahiwal cross. On the other hand, Holstein cross and Red Chittagong was nearly similar. Red Chittagong milk sample showed the highest TS value and the lowest value was observed from Holstein cross. The highest protein value was found from Red Chittagong and the lowest from Holstein cross but the protein content of other two genotypes were nearly similar.
\end{abstract}

Key words : Genotype, Dairy cow, Milk, Composition

\section{Introduction}

Milk is highly nutritious food. It contains on an average $87.25(\%)$ water, $3.80(\%)$ fat, $3.50(\%)$ protein, $4.80(\%)$ of lactose and $0.07(\%)$ minerals. Besides milk contains considerable amounts of fat soluble vitamins (Vit-A, D, E \& K) and water soluble vitamins (Vit- B complex and Vit-C) (Eckles et al., 1981). The value of milk is remarkable and has been considered as a balance diet. Milk fat differs from other animal fat in that it has many more kinds of fatty acids. Fat helps in the proper metabolism of sugars and serves as carrier of the fat-soluble vitamins A, D, E and $\mathrm{K}$. The essential amino acids like tryptophan and lysine are present in large quantity in milk, which are deficient in vegetable protein. Milk protein requires for formation of new tissues, repair of broken down tissue and overall development of the body system. The availability of milk in our country is only $33.00 \mathrm{ml}$ per head per day whereas; the requirement is $250 \mathrm{ml}$ per head per day (DLS, 2001). Although milk is an important diet of people of all ages, but its quality depends on lot of factors. Genotype of cows is an important factor which can influence the quality of milk. Therefore, the present research work was undertaken to study the quality of milk from different genotype.

\footnotetext{
${ }^{1}$ Manager, Bangladesh Agricultural University Dairy Farm, BAU, Mymensingh-2202, Bangladesh

${ }^{2}$ Department of Dairy Science, Bangladesh Agricultural University, Mymensingh-2202, Bangladesh
}

(Received : July 23, 2008) 
Bang. J. Anim. Sci. 2008, 37 (1)

\section{Materials and Methods}

The present experiment was conducted at BAU Dairy Farm under the Department of Dairy Science, BAU, Mymensingh during the period from $1^{\text {st }}$ July to $30^{\text {th }}$ December 2005 . For this experiment a total 48 dairy cows belonging to different genotypes such as Jersey cross, Sahiwal cross, Holstein Friesian cross and Red Chittagong were selected and the numbers of the animals of each of the genotypic classes were twelve. The animals of at least three lactation periods were only used for this study. Animals were placed hygienically in individual stall in a well - ventilated "face out stanchion barn" house. Attempts were made to keep all animals under same management condition. Calves were allowed to suckle during milking for milk-let down only. Cows were milked by hand twice daily, at morning (6:00 A.M.) and evening (4:00 P.M.) and keeping their calves at their feet during milking. Wheat bran, oil cake and rice polish were supplied to the cows. Morning and evening milk was recorded to get actual milk yield of cows in a day. Raw milk samples were collected and were transferred to the Dairy Technology Laboratory by keeping them in an ice-containing box for analysis. The parameters used to monitor the quality of milk were Specific gravity (sp. gr.), Acidity test, Fat test, Protein test, Solids-not-fat test, Total solids (TS) test. Specific gravity was performed by using Quevenne Lactometer according to the procedure described by Aggarwala and Sharma (1992). Fat test was performed by Gerber fat test methods. Acidity of milk was determined by titration method as per procedure described in AOAC (1971). Protein test was done by Kjeldhal method. Data collected from this experiment was analyzed statistically to find out the differences between treatment means. "Mstat" statistical package was used for this purpose. F-value was calculated to find out significant difference between treatment means. LSD (least Significance Difference) was also used for the comparison between the treatment means.

\section{Results and Discussion}

\section{Specific gravity}

There was significant difference $(\mathrm{P}>0.01)$ within the specific gravity of milk collected from different genotype of dairy cows milk (Table 1). It was observed that the higher specific gravity of milk was obtained from Jersey cross and Red Chittagong genotype, which was significantly higher $(\mathrm{P}<0.01)$ than the other genotype of dairy cows. The normal range of specific gravity of whole milk is 1.027 to 1.035 with an average of 1.032 (Eckles et al., 1981). Salam (1993) carried out an experiment on the physical, chemical and microbiological quality of milk produced in Baghabarighat Dairy Plant (BDP). He reported that average specific gravity of milk of BDP was $1.02757 \pm 0.001$.

Table 1. Milk quality characteristics of different genotypes of BAU dairy farm

\begin{tabular}{|c|c|c|c|c|c|c|}
\hline \multirow{2}{*}{$\begin{array}{c}\text { Parameters } \\
(\%)\end{array}$} & \multicolumn{4}{|c|}{ Genotypes } & \multirow{2}{*}{ LSD } & \multirow{2}{*}{$\begin{array}{c}\text { Levels of } \\
\text { significant }\end{array}$} \\
\hline & Holstein cross & Jersey cross & Sahiwal cross & Red Chittagong & & \\
\hline Fat & $4.28^{b} \pm 0.92$ & $5.20^{\mathrm{a}} \pm 0.55$ & $5.01^{\mathrm{a}} \pm 0.73$ & $5.60^{\mathrm{a}} \pm 0.91$ & 1.214 & $* *$ \\
\hline Protein & $3.11^{\mathrm{ab}} \pm 0.76$ & $3.82^{\mathrm{ab}} \pm 0.21$ & $3.99^{\mathrm{ab}} \pm 0.58$ & $4.06^{\mathrm{a}} \pm 0.29$ & 0.925 & $* *$ \\
\hline SNF & $8.49^{\mathrm{b}} \pm 0.42$ & $9.57^{\mathrm{a}} \pm 0.48$ & $8.08^{\mathrm{b}} \pm 0.58$ & $8.70^{b} \pm 0.25$ & 0.732 & $* *$ \\
\hline TS & $12.95^{\mathrm{b}} \pm 1.33$ & $14.2^{\mathrm{a}} \pm 0.95$ & $13.16^{\mathrm{ab}} \pm 1.01$ & $14.25^{\mathrm{a}} \pm 0.96$ & 2.080 & $* *$ \\
\hline Sp. gravity & $1.030^{\mathrm{b}} \pm 0.0017$ & $1.032^{\mathrm{a}} \pm 0.0012$ & $1.028^{\mathrm{c}} \pm 0.0017$ & $1.030^{\mathrm{b}} \pm 0.0032$ & 0.0073 & $* *$ \\
\hline Acidity & $0.145^{\mathrm{b}} \pm 0.023$ & $0.146^{\mathrm{b}} \pm 0.073$ & $0.118^{\mathrm{c}} \pm 0.025$ & $0.165^{\mathrm{a}} \pm 0.014$ & 0.0012 & $* *$ \\
\hline
\end{tabular}

** Significant $(\mathrm{P}<0.01)$ 


\section{Fat}

Fat content of milk obtained from four different genotypes were significant at $1 \%$ level of probability (Table 3). The highest fat (\%) was observed from Red Chittagong, and Sahiwal cross and the lowest fat (\%) from Holstein cross. Generally fat Content ranged between 4.28 to 5.60\% Uddin et al., 2003 studied the fat content of milk collected from different farmers. It is reported that the fat content was 3.6 and $5.70 \%$ respectively. On the other hand milk fat collected from Jersey cross, Sahiwal cross and Red Chittagong was higher may be due to the supply of more concentrate feed and dry roughage specially rice straw offer on account of their milk production which supported by Hossain (1968) who found that milk fat of indigenous cows was $4.60 \% \pm 0.64$. And the Holstein cross of high yielding animal, which reduce the fat content of milk sample. This result agree with Islam et al. (1992) who reported 2.3 to 3.60 fat for market milk supply in Mymensingh town (Bangladesh).

\section{Protein}

The protein percentage of milk collected from different genotype differed significantly $(\mathrm{P}<0.01)$ (Table 3). The highest protein value was found from Red Chittagong and the lowest from Holstein cross which was similar to Jersey cross and Chittagong.

\section{Solids-not-fat (SNF)}

The SNF Percentage of milk collected from different genotype was statistically significant $(\mathrm{P}<0.01)$ (Table 2). The highest SNF value was obtained from Jersey cross and the lowest from Sahiwal cross which was similar to Holstein cross and Red Chittagong. Yadav and Saraswat (1982) in an experiment was done on the market milk of different genotype and found that SNF. content varies from 6.39 to $8.86 \%$, which agrees with these findings. According to the US Public Health Services (1965) milk contains minimum $8.5 \%$ solids-not-fat. In the findings of this experiment it is observed that all the genotypes SNF content varying from 8.08 to $9.57 \%$. So, the SNF content of present study was little lower than that of the SNF (\%) reported by the US Public Health Services (1965). Talukder (1989) observed that the average SNF content of milk collected from farmers and local market of Trishal thana under Mymensingh district were 8.61 and $7.13 \%$ respectively.

\section{Total solids (TS)}

Statistical analysis showed that the difference between the TS content of milk samples collected from different genotype was significant $(\mathrm{P}<0.01)$ (Table 3). Red Chittagong milk sample showed the highest TS value which was statistically similar with Jersey and the lowest observed from Holstein cross. Rahman (1992) observed that total solids content of milk collected from Manikganj Chilling Center, Tangail Chilling Centre, Takerhat Pasteurization Plant and BDP were 11.48, 10.72 and $12.91 \%$ respectively. The average total solids content of milk reported by Rahman (1992) was lower than the TS content of present study. This was due to the fact that Rahman (1992) collected milk from different areas and the samples were composite. This was the main causes of lower TS content of milk obtained by Rahman (1992).

\section{Specific gravity}

The specific gravity was obtained in Red Chittagong genotype and lowest value was found in Sahiwal genotype and they differed significantly.

\section{Acidity}

The average acidity percentage of milk of different genotype of dairy cows of BAU dairy farm differed significantly at $(\mathrm{P}<0.01)$. The highest acidity percent was observed $(0.165 \pm 0.014)$ in Red 
Bang. J. Anim. Sci. 2008, 37 (1)

Chittagong and the lowest acidity percent $(0.118 \pm 0.025)$ from Sahiwal cross. The normal range of acidity of cows' milk is 0.13 to $0.18 \%$ lactic acid (Lampert, 1970). The acidity of milk of the four different genotypes was found within the normal range but acidity of milk collected from Sahiwal was found comparatively lower. Besides, acidity of milk collected by chilling plant depends sometimes on the time required from milking up to receiving milk in that plant. Besides the higher content of SNF. in milk may show slightly higher percentage of acidity and lower contents, shows lower acidity of milk. Islam et al. (1990) reported that acidity percentage of market milk were $0.14 \pm 0.010$. Ito (1966) reported that the acidity percentage of cows' milk was $0.142 \pm 0.0074$, which was similar to this experimental result of acidity percentage. From the normal acidity value of milk of four genotypes it may be pointed out that all the milk samples were fresh during laboratory analysis. From the above discussion it was observed that Red Chittagong cows were found superior to other genotypes of dairy cows used in the study.

\section{Literature Cited}

Aggarwala, A. C. and Sharma. 1961. A Laboratory Manual of Milk Inspection, $4^{\text {th }}$ edition, Asia Publishing House, Bombay, Kolkata, New Delhi, India.

AOAC. 2003. Official Methods of Analysis ( $15^{\text {th }}$ ed.). Association of Official Analytical Chemists, Arlington, Virginia, USA.

DLS, 2001. Department of Livestock Services Annual Report. Government of the People's Republic of Bangladesh.

Eckles, C. H., Conbs, W. B. and Maey, H. 1981. Milk and milk products fourth edition, McGrow-Hill Book Company, New York, USA.

Hossain, A. M. 1968. A study of average percentage of fat, total solids, solids-not-fat content of local cows milk and the variation of milk fat percentage with the stage of lactation. M.Sc. (AH) Dairy Science, East Pakistan (Now Bangladesh) Agricultural University, Mymensingh.

Islam, K. M. A. 1990. A study on the milk yield, composition and energy value of indigenous cows milk at surrounding villages of Manikgonj Milk Chilling Centre, Milk Vita Manikgonj. M.Sc. Thesis. Dairy Sci. Dept. BAU.

Islam, M. A. 1992. A comparative economic analysis of milch cows and buffalo's in two selected village of Mymensingh district in Bangladesh, M.Sc. thesis, Department of Agricultural Finance, BAU, Mymensingh.

Ito, R. 1996. Variation in the quality of raw Milk Jap. J. Dairy Science, 15 (1) : All - A15.

Lampert, I. M. 1970. Modern Dairy Production. $3^{\text {rd }}$ Ed. Chemical Publishing Company. Inc. New York. Leon. J, T, Park, S. Y., Korea, IK. and Kin, H, U. 1983. Quality of raw milk in Korean J. Dairy Sci., 5(1) : 22-28.

Rahman, M. S. 1992. Dairy Development in Bangladesh. Proceeding of Fourth National Conference 1992. Bangladesh Animal Husbandry Association. pp. 84- 88.

Salam, A. M. 1993. The studies on the physical, chemical and microbiological qualities of milk produced in Baghabarighat Milk Shed Area. M.Sc. Thesis. Department of Dairy Science, BAU.

Talukder, O. G. MD. 1989. A study on physical and chemical qualities of milk collected from different markets and villages of Trisal upazila M.Sc. Thesis. Department of Dairy Science, BAU.

Uddin, M. M., Islam, M. N., Ahmed, S. and Siddiki, M. S. R. 2003. Production performances of different genetic groups of dairy cows under ideal farm conditions. J. Bangladesh Soc. Agric. Sci. Technol. 2(1\&2) : 81-84

U. S. Public Health Service, 1965. Grade A Pasteurized Milk Ordinance.

Yadav. A. N. and Saraswat, B. L. 1982. Note on the physical and chemicals qualities of market in Varanasi town, India, Asian, J. Res. 1(1) : 74-76. 